\title{
Social Media Advertising and Consumer Perception on Purchase Intention
}

\author{
Widjojo Suprapto ${ }^{1^{*}}$, Ken Hartono $^{1}$, and Hakim Bendjeroua ${ }^{2}$ \\ ${ }^{1}$ Department of Management, Faculty of Business and Economics, Petra Christian University, \\ J1. Siwalankerto 121-131, Surabaya 60236, Indonesia \\ ${ }^{2}$ Departement of Sciences of Management, Faculty of Economics, Management and Commercial \\ Sciences, Kasdi Merbah University - Ouargla Ghardaia Road, BP.511, 30,000, Algeria
}

\begin{abstract}
In the era of Industrial Revolution 4.0, many companies are using social medias as one of their promotional tools, especially Instagram. The aim of this research is to investigate the influence of Instagram advertising and consumer perception on purchase intention in local building material stores. As this research is using a quantitative approach, the data are collected using questionnaires. The population of this research is the customers who have done several purchases and have followed the stores' Instagram accounts. Out of the whole population, a number 100 respondents are selected through a purposive sampling technique. The collected data are processed using a SmartPLS program, with the results of no significant influence between Instagram advertising and purchase intention. However, the Instagram advertising has a significant influence on purchase intention through customer perception as the Instagram advertising has a significant influence on customer perception. Therefore, customer perception acts as the intervening variable in this research.
\end{abstract}

Keywords: Buying interest, instagram promotion, purchase behavior.

\section{Introduction}

The internet has become a global phenomenon and created various opportunities. Internet adoption has included various aspects of human life and has become an integrated part of various corporate systems. The level of internet penetration in Indonesia has been found to grow so rapidly, especially in the past decade. Statistical reports released by BPS show that in 2017 alone, the level of internet users in Indonesia has grown to $143.26 \times 10^{6}$. These results mean that more than $50 \%$ of Indonesian people have been internet literate [1]. The following data is from the Indonesian Internet Service Providers Association (APJII) which shows the level of growth of internet users in Indonesia.

Isparmo also explains that although the growth rate of internet users in Indonesia has grown so high, the percentage of the country's population using the internet (penetration) has only reached $54.68 \%$ [1]. This means that only about half of the total population of

* Corresponding author: joe.suprapto@petra.ac.id 
Indonesians who are just using the internet in their daily lives. The high growth of internet users makes Indonesia as the potential market to develop commerce through the internet. Gallino and Moreno explain that online retailing has grown steadily over the past few years, even some retailers are found to operate exclusively through online channels. The online retailer channel is no longer an experiment for now, but a relevant and growing part of their business [2].

Chadwick, Hart, and Doherty explain that consumer demand for the internet is a key factor that can ultimately encourage widespread internet adoption by retailers. The internet plays a supporting role in existing marketing activities [3]. The role adopted by the internet can ultimately determine consumer demand for online shopping and by developing "cyber retail." The internet has been used in three main ways to facilitate retail marketing. The most basic thing is the means to communicate information about retail organizations, their products and services. The internet, as a more proactive marketing tool, invites consumers interactively to access websites to get more product information to facilitate their purchasing decision making processes. Information at the same time can also provide valuable consumer data for retailers to enable greater targeting. Internet retail offers a retail experience that is completely different from fixed location retailing. Comparing shopping prices on a number of larger sites will be easier and can be achieved in a matter of minutes.

Indonesia currently has many companies that make internet-based sales. This phenomenon is expected to open the door to new opportunities for e-commerce sites and businesses. Driving factors the emergence of e-commerce businesses in Indonesia, one of which, are the increased penetration of smartphones and the internet, intensive foreign investment in leading platforms, Indonesia's growing middle class, and improved online payments that all contribute to market growth and the sophistication of local players. Changes to positive regulations by the Indonesian government are also improving well.

The high level of internet usage is also increasingly supported by the emergence of various social media and internet devices. Akhtar, Tahir, and Asghar explain that technological innovations such as mobile phones and the internet have given rise to social media, which is responsible for creating a new era of marketing [4]. Social media is referred to as an electronic device that is widely accessible and relatively inexpensive that allows individuals to publish and access information, build relationships, and collaborate in joint efforts. This tool represents a computer-mediated tool that enables companies and people to create, share, or exchange career information, ideas, and career interests in communities and virtual networks. This is actually a group of internet-based applications that are built on a technological and ideological foundation of the web and allow the creation and exchange of users and the content they produce. Facebook, Google, Twitter, Instagram, WhatsApp, Yahoo, Pinterest and others are the most commonly used social networking tools.

The vast potential of sales via the internet is the reason for adopting this online sales system at conventional retail stores. There are many types of businesses that market their products online and have succeeded in finding them, such as stores that sell clothes, shops selling electronic equipment, cellular devices, and food. The object of research in the study is the building material stores which are located in smaller cities around Sidoarjo Regency, a growing area next to Surabaya. These stores are selling a variety of products ranging from small building materials such as paints, bolts, carpentry tools, to heavy or large building materials such as cement, pipes, sand, concrete, plywood, and others. The target market is mostly for individual households, private and government contractors and companies in government projects and private projects.

These stores are incorporating social media advertising as a tool to reach wider markets and also increase consumer purchase intentions as they have been successful in carrying out their conventional marketing and recognized around their surrounding communities as the 
building material stores. The use of social media can facilitate retail marketing which is useful to assist the marketing process in trading products that are owned. Through social media, these stores can also communicate information about products and others.

Sales via the internet are basically influenced by social media advertising. At present, the application of Instagram promotion is mostly made by sellers because the impact is so great considering the influence of the internet which has been so great. Harshini explains that with social media advertising efforts, sellers can quickly expand market share and gain increased sales [5]. The features available in social media that are very helpful such as the interaction between sellers and buyers through the comments column are one of the causes of market share expansion. In this column, some prospective buyers can also find out the credibility of the seller by reading comments from others. Social media is also used as a means of entertainment so that when inserted ads, it will be more striking to prospective buyers. The strength of influence will influence in generating consumer purchase intentions [6].

Purchase intention may arise because the contents of advertising in social media are more attractive. Ads can be displayed in various forms, such as videos or just pictures that are uploaded and given information. The power of visual influence of advertisements displayed on social media can significantly increase consumer purchase intentions. Research from Wang et al., also explains that advertising that appears too often on social media will actually inhibit the purchase intention [6]. This is because these advertisements are seen as disrupting consumer pleasure, interrupting surfing activities, even in the frequency that these advertisements are often considered annoying. Consumers can also feel compelled to buy the advertised product because the advertisements displayed are arranged in such a way by social media applications. Sophisticated algorithms that exist in social media programs enable the application to identify each owner of a social media account based on hobbies, preferences, and activities. The increase in purchase intention will make the seller's marketing scope also increase.

Yang and Lee explain that consumer purchase intention can be influenced by other things, such as consumer perception [7]. Consumer perception is formed as a result of visual input received by consumers. An example is an advertisement that often appears on social media. Wang et al. describe that advertisements that appear on social media can be the ones that are paid services or indeed social media accounts that intentionally upload product advertising content owned by the account [6]. All forms of advertisements that appear are visual inputs that have different perceptual effects for each consumer but found that many consumers can feel annoyed or bored with these advertisements. However, when the advertisement is displayed in an attractive form, it can lead to purchasing intention. In short, consumer perceptions of advertisements that appear on social media can influence consumer purchase intentions on the advertised product. Therefore, this research seeks to maximize the use of social media that are already owned to develop marketing advertisement and find new consumers through social media, and learn whether social media can be used as a tool to achieve these goals and trigger consumer purchase intentions. The social media accounts used in this study are Instagram and WhatsApp.

\section{Research framework and hypothesis}

The following is the research framework and hypothesis for this research. 


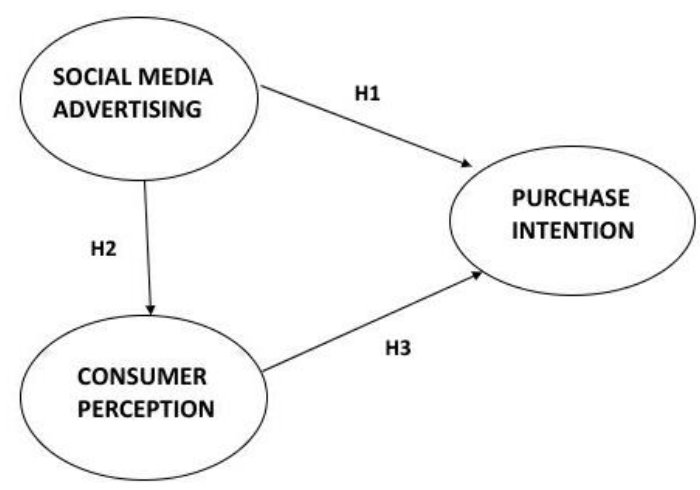

Fig. 1. Research framework

The hypotheses are constructed as follows:

H1: It is suspected that social media advertising has a positive significant influence on consumer purchase intention.

$\mathrm{H} 2$ : It is suspected that social media advertising has a positive significant influence on consumer perception.

H3: It is suspected that consumer perception has a positive significant influence on purchase intention.

\section{Research method}

As the aim of the research is to investigate the influence of social media advertising and consumer perception on the purchase intent, this research belongs to quantitative research. The population in this study are all consumers of the stores that use Instagram and follow the store accounts. From the population, the samples are drawn using a non-probability sampling technique as the sampling respondents have to meet several requirements [8]. The number of samples in this research is 100 respondents [9]. The data are collected from the respondents using questionnaires. Each statement in the questionnaire is valued by the Likert Scale of five levels, ranging from (1) as strongly disagree to (5) as strongly agree [8]. Then, the data are processed with smartPLS software to obtain the results. Two steps of PLS are conducted: the outer model to test the validity and reliability and the inner model to test the hypothesis with the t-test [10].

\section{Analysis and discussion}

\subsection{The result of the Outer Model}

The first step in PLS analysis is to test the validity and reliability. These tests are obtained from the outer model, such as the convergent validity, the discriminant validity, and the composite reliability. The outer model is described in Figure 1. 


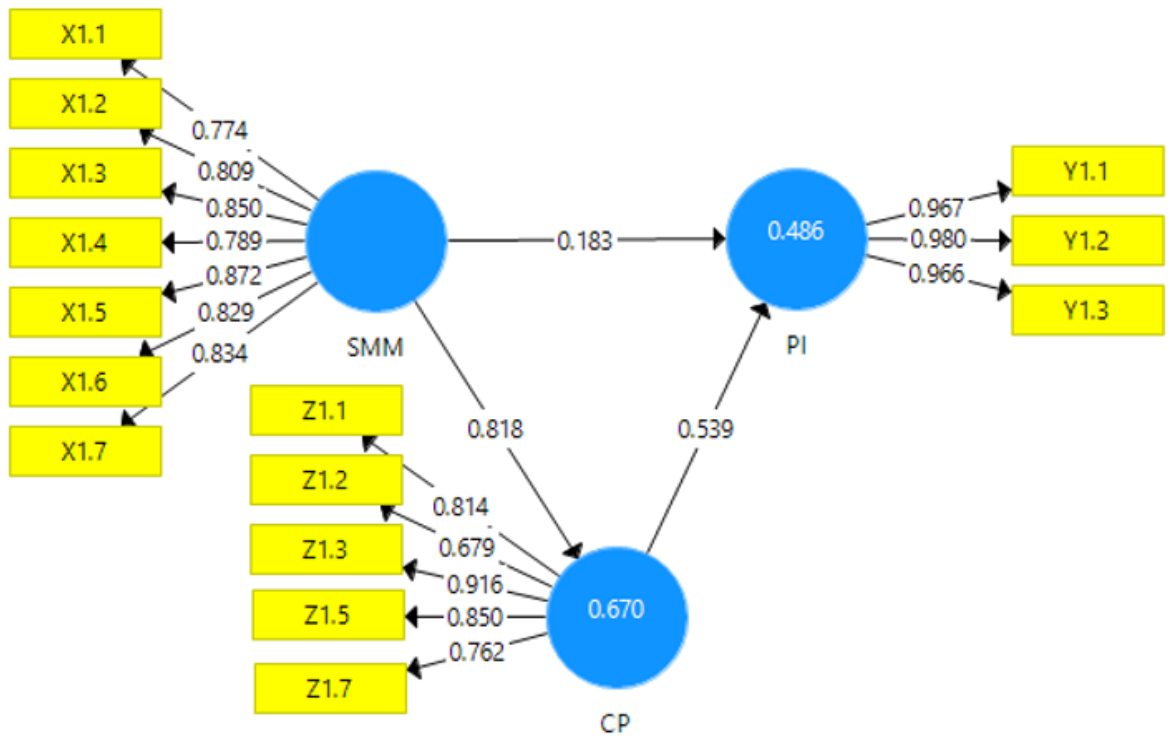

Fig. 2. The outer model

The convergent validity is depicted by the value along with the arrows from the variables to their indicators. It shows that all values are above 0.500 so all have met the requirement of convergent validity. Therefore, all indicators are valid.

The discriminant validity of the reflexive measurement model is calculated based on the cross-loading value of the manifest variable against each latent variable. From the outer model, it is obtained that the cross-loading value of each indicator is higher than another latent variable, so all indicators are valid. It can be seen also from the values of AVE, which are higher than 0.5 in Table 1

The composite reliability can be observed in Table 1 .

Table 1. Composite Reliability

\begin{tabular}{lccc}
\hline & Composite Reliability & Cronbach's Alpha & AVE \\
\hline Social media advertising & 0.936 & 0.921 & 0.677 \\
Consumer perception & 0.903 & 0.866 & 0.653 \\
Purchase intention & 0.980 & 0.970 & 0.943 \\
\hline
\end{tabular}

The table above shows that all variables have composite reliability and Cronbach's alpha values greater than 0.6 , so it can be said that each research variable has met the requirements for composite reliability and Cronbach's alpha. And it can also be said that the variables above are reliable.

\subsection{The result of the Inner Model}

The model surrenders to the value of $\mathrm{R}$-square. The $\mathrm{R}$ square is depicted in Table 2 . The $\mathrm{R}$ square of the purchase intention is 0.486 , meaning that the social media advertising variable affecting the purchase intention is $48.6 \%$ while the rest is affected by other variables not included in this research. The $\mathrm{R}$ square of the consumer perception is 0.670 , meaning that the social media advertising variable affecting the consumer perception is $67.0 \%$, while the rest is affected by other variables not included in this research. 
Table 2. The result of R square

\begin{tabular}{cc}
\hline & $\mathbf{R}^{\mathbf{2}}$ \\
\hline Purchase Intention & 0.486 \\
Consumer Perception & 0.670 \\
\hline
\end{tabular}

Knowing the $\mathrm{R}$ square, the Q square can be calculated with this rule:

$$
\begin{gathered}
\mathrm{Q}^{2}=1-\left(1-\mathrm{R}^{2} 1\right)\left(1-\mathrm{R}^{2} 2\right) \\
\mathrm{Q}^{2}=1-(1-0.670)(1-0.486) \\
\mathrm{Q}^{2}=0.83038
\end{gathered}
$$

From the above calculation, the $\mathrm{Q}^{2}$ value is 0.83038 (value closer to 1 ), thus indicating that the model has predictive relevance.

Then, the result of the bootstrapping is displayed in Graph 3.

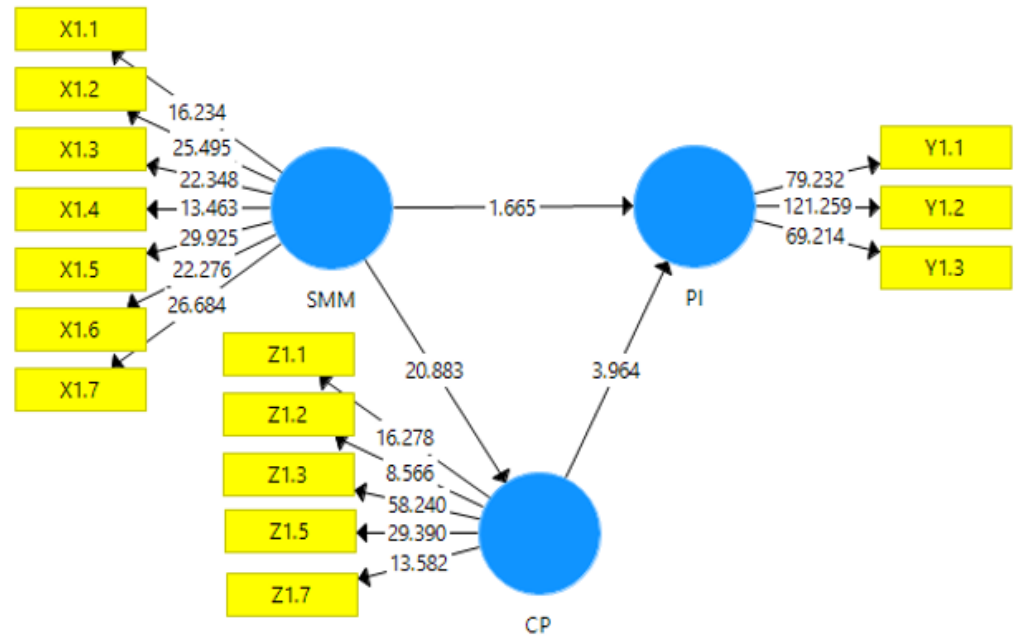

Fig. 3. The inner model

The inner model is summarized in Table 3 and seen as the result of the hypothesis testing through the value of the T-Statistics and the $\mathrm{P}$ values.

Table 3. The hypothesis tests

\begin{tabular}{llccc}
\hline & & O & T- Statistics & P Values \\
\hline H1 & $\mathrm{SMM} \rightarrow$ PI & 0.183 & 1.665 & 0.097 \\
H2 & $\mathrm{SMM} \rightarrow$ CP & 0.818 & 20.883 & 0.000 \\
H3 & $\mathrm{CP} \rightarrow$ PI & 0.539 & 3.964 & 0.000 \\
\hline
\end{tabular}

\subsection{Discussion}

\subsubsection{The influence of social media advertising to purchase intention}

The results of this study indicate that social media advertising has no significant influence on purchase intention. It is proven by the value of the T-Statistic of 1.665 which is smaller 
than 1.96. Thus $\mathrm{H} 1$ is rejected. The results obtained are different from the results of previous studies conducted by Harshini [5], Zhu and Zhang [11], and Wang et al., [6]. This means that Instagram advertising applied by these building material stores is not able to increase consumer purchase intention. Research from Wang et al. examines the effect of social media on purchase intentions to use social media in general. The objects in previous studies are retail products such as fashion, food, and accessories [6].

\subsubsection{The influence of social media advertising to consumer perception}

The results of this study indicate that social media advertising has a significant positive effect on consumer perception. It is shown by a t-value of 20.883 , which is greater than 1.96. Thus $\mathrm{H} 2$ is accepted. The results obtained further confirm the results of previous studies conducted by Ali et al., [12] and Athapaththu and Kulathunga [13].

\subsubsection{The influence of consumer perception to purchase intention}

The results in this study indicate that consumer perception has a significant positive influence on purchase intention, which is marked by a statistical t-value of 3.964. As the value is greater than 1.96 , the $\mathrm{H} 3$ is accepted. The results confirm the results of previous studies conducted by Bhalla [14], Keegan and Rowley [15], and Wang et al. [6]. This means that consumer perception is seen to increase consumer purchase intention.

\section{Conclusion}

The conclusions obtained from the results of the analysis show that instagram promotion variable does not have a significant positive effect on purchase intention. However, the consumer perception variable has a significant positive effect on purchase intention, and the instagram promotion variable has a significant positive effect on consumer perception so that the third hypothesis is accepted. Consumer perception as an intervening variable acts to strengthen the relationship between instagram promotion and purchase intention.

\section{References}

1. Isparmo, APJII, 1,1:1-39(2018). [in Bahasa Indonesia]. https://www.apjii.or.id/content/read/39/342/Hasil-Survei-Penetrasi-dan-PerilakuPengguna-Internet-Indonesia-2017

2. S. Gallino, A. Moreno, SSRN Electronic Journal, 9,17:1-24(2012). https://pubsonline.informs.org/doi/abs/10.1287/mnsc.2014.1951

3. C. Hart, N. Doherty, F. Ellis-Chadwick, European Journal of Marketing, 34,8:954974(2000). https://www.emeraldinsight.com/doi/abs/10.1108/03090560010331441

4. N. Akhtar, M. Tahir, Z. Asghar. International Review of Social Sciences, 4,10:385395 (2016). http://irss.academyirmbr.com/papers/1467281650.pdf

5. C. S. Harshini, International Journal of Current Engineering and Scientific Research, 2,10:110-116(2015). http://troindia.in/journal/ijcesr/vol2iss10/110-115.pdf

6. L. Wang, F. Ampiah, L. Xu, X. Wangs, Proceedings of the 2014 International Conference on Mechatronics, Electronic, Industrial and Control Engineering, 5,16:217-221(2014). https://www.atlantis-press.com/proceedings/meic-14/15015

7. F.A. Konuk. British Food Journal, 117,2:793-804(2015). https://www.emeraldinsight.com/doi/abs/10.1108/BFJ-10-2013-0305

8. Sugiyono, Statistika untuk penelitian. [Statistics for research]. Bandung: Alfabeta (2018). [in Bahasa Indonesia]. https://www.goodreads.com/book/show/29974706statistika-untuk-penelitian 
9. S. Lemeshow, D.W. Hosmer, J. Klar. Adequacy of Sample Size in Health Studies.

USA: World Health Organization (1994).

https://apps.who.int/iris/handle/10665/41607

10. J. F. Hair, W.C. Black, D.J. Babin, Multivariate Data Analysis, New Jersey: Pearson Prentice Hall (2010). https://www.pearson.com/us/higher-education/program/HairMultivariate-Data-Analysis-7th-Edition/PGM263675.html

11. F. Zhu, X.M. Zhang, Journal of Marketing, 74,2:133-148(2010). https://journals.sagepub.com/doi/10.1509/jm.74.2.133

12. Z. Ali, M. A. Shabbir, M. Rauf, A. Hussain, International Journal of Academic Research in Accounting, Finance and Management Sciences, 6,3:69-77(2016). https://www.researchgate.net/publication/308653428_To_Assess_the_Impact_of_Soci al_Media_Marketing_on_Consumer_Perception

13. C. Athapaththu, D. Kulathunga, International Business Research, 11,10:111-128 (2018).

https://www.researchgate.net/profile/Jayani_Atapattu/publication/329883979 Factors _Affecting_Online_Purchase_Intention_Effects_of_Technology_and_Social_Commer ce/links/5c204450299bf12be395ce0c/Factors-Affecting-Online-Purchase-IntentionEffects-of-Technology-and-Social-Commerce.pdf

14. P. Bhalla, I.S. Ali, A. Nazneen, European Journal of Scientific Research, 149,4:362368(2018).

https://www.researchgate.net/profile/Pretty Bhalla/publication/326572588_Consumer Perception_and_Purchase Intention_of_Electric_Vehicles_in_India/links/5ba0931c9 2851ca9ed11caa4/Consumer-Perception-and-Purchase-Intention-of-Electric-Vehiclesin-India.pdf

15. B.J. Keegan, J. Rowley, Management Decision, 55,1:15-31(2017). https://www.researchgate.net/publication/309563351_Evaluation_and_decisionmaking_in_social_media_marketing 